\title{
KESADARAN FONOLOGI PADA ANAK USIA 3 TAHUN
}

\author{
ASTI RAMADHANI ENDAH LESTARI \\ Universitas Indraprasta PGRI, Indonesia \\ asti.ramadhani@unindra.ac.id
}

\begin{abstract}
ABSTRAK
Penelitian ini bertujuan untuk mengetahui tingkat kesadaran fonologi pada anak usia 3 tahun. Kesadaran fonologi merupakan salah satu keterampilan penting dalam kegiatan persiapan belajar membaca bagi anak usia dini. Responden dalam penelitian ini adalah tiga orang anak usia tiga tahun yang terdiri atas dua perempuan dan satu lakilaki. Penelitian dilakukan dengan menggunakan metode deskriptif kualitatif. Teknik pengumpulan data dilakukan dengan observasi dan uji kerja. Uji kerja terhadap responden dilakukan dengan menggunakan pedoman uji kerja yang diadaptasi dari PAST (Phonological Awareness Skill Test) yang dikembangkan oleh GRRC (Green River Regional Education Center), Kentucky, Amerika Serikat. Hasil penelitian menunjukkan bahwa anak usia 3 tahun sudah memiliki kesadaran fonologi yang baik pada tingkatan pemenggalan kalimat, pengenalan bunyi berima, produksi bunyi berima, dan penggabungan suku kata.
\end{abstract}

Kata kunci : kesadaran fonologi, anak usia dini, fonologi

\section{PENDAHULUAN}

Perkembangan merupakan sebuah pertumbuhan, memiliki tahapan yang proses perubahan yang didukung dengan berurutan dan memiliki pola-pola bertambahnya struktur dan fungsi tubuh tertetentu. Seorang manusia mengalami yang lebih kompleks. Perkembangan perkembangan yang signifikan pada masa seorang anak berkorelasi dengan bayi atau balita. 
Salah satu perkembangan yang dialami oleh bayi adalah perkembangan bahasa. Sejak dilahirkan bayi sudah bisa berkomunkasi meskipun hanya dengan tangisan ataupun bahasa non verbal. Seiring pertumbuhan dan perkembangannya, bahasa bayi juga mengalami perkembangan. Bayi belajar untuk memahami ujaran, memproduksi bunyi, hingga memproduksi kata, frasa, dan klausa. Perkembangan bahasa harus terus didtimulasi hingga akhirnya seseorang dapat berkomunikasi dengan baik.

Hal ini diperkuat oleh Traxler (2011: 329-330) yang mengatakan bahwa fonem merupakan kumpulan kata-kata pada bahasa baru bayi. Seorang bayi harus dapat mengatur perbedaaan antara setiap suara yang ia dengar. Faktor yang mempersulit proses ini adalah suara merupakan sesuatu yang unik karena tidak ada dua bunyi yang identik. Misalnya, beberapa pembicara memiliki suara yang lebih tinggi dari yang lain atau beberapa pembicara mengeluarkan suara lebih cepat dari yang lain. Terlepas dari perbedaan antara suara ujaran yang berbeda, orang dewasa mempersempit sinyal akustik yang beragam secara luas menjadi sejumlah kategori (sekitar 40 dalam bahasa Inggris).
Salah satu perkembangan bahasa untuk anak usia dini adalah munculnya kesadaran fonologi. Kesadaran fonologi merupakan kemampuan seseorang yang berhubungan dengan kepekaan pada bahasa lisan. Kuhl (2008: 979 ) mengatakan bahwa untuk memperoleh bahasa, seorang anak harus menemukan perbedaan fonetik yang akan digunakan dalam budaya bahasa mereka dan melakukannya dengan diskriminasi antara hampir semua unit fonetik bahasa yang diketahui. Dardjowidjojo (2000: 21) mengatakan bahwa dalam komponen pemerolehan fonologi, bentuk sifat keabsolutannya sangat tampak dalam arti bahwa bunyi tidak mungkin dikuasai anak sebelum bunyi lain dikuasainya, meskipun kendala seperti ini tidak berlaku untuk seluruh bunyi pada bahasa tersebut.

Copple dan Bredekamp (2009:5) mengatakan bahwa perkembangan kesadaran fonologi anak dimulai saat usia 3 - 4 tahun (preschooler). Pada tahap ini anak mulai mengenal irama, aliterasi, suku kata, bunyi awal dan bunyi akhir yang sama (onset \& rime), dan bunyi. Pada saat anak memasuki usia 5-6 tahun, kesadaran fonologi anak berkembang kepada kesadaran fonemik yaitu kemampuan untuk memanipulasi unit bunyi terkecil dari kata-kata lisan. 
Misalnya anak bisa mengganti bunyi /i/ kesadaran fonologi anak dapat dilihat pada kata /sapi/ dengan bunyi /u/ menjadi pada gambar di bawah ini kata /sapu/. Secara visual, perkembangan

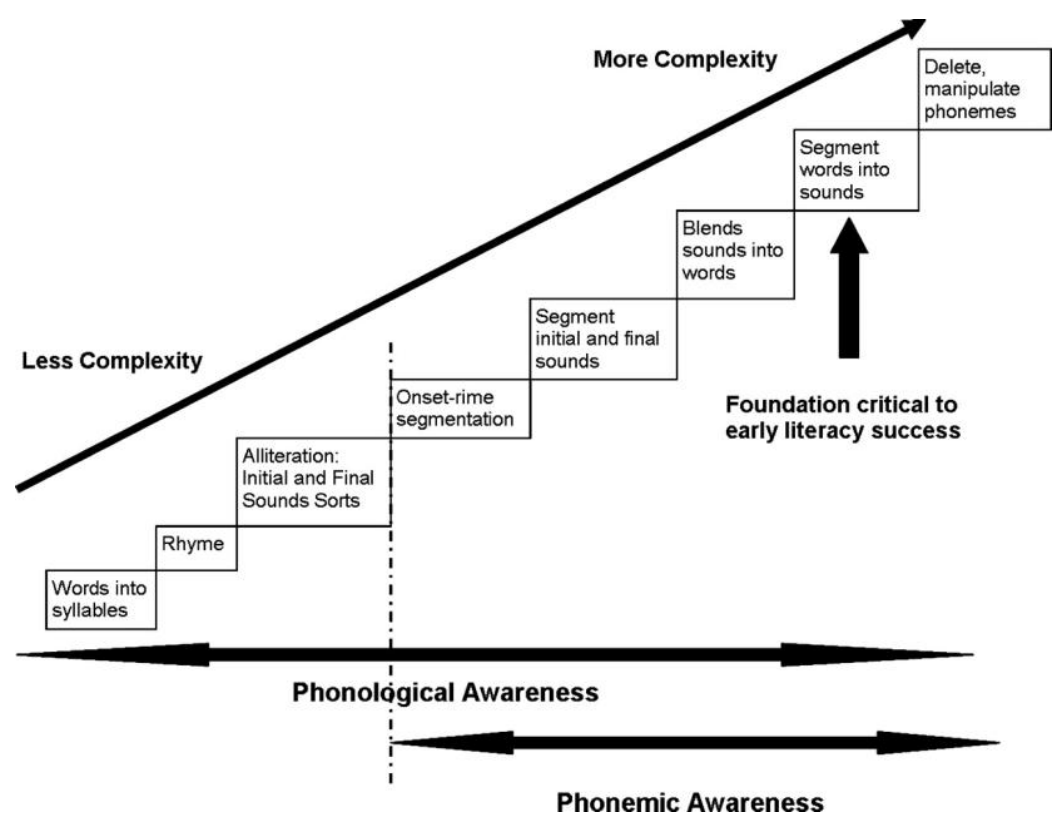

gambar 1

perkembangan kesadaran fonologi anak

Kesadaran fonologi merupakan Duranovic, dkk ( 2012: 15) yang salah satu aspek penting yang banyak membuktikan bahwa kesadaran fonologi dikaitkan dengan pembelajaran membaca. merupakan predictor yang baik dalam Hal ini didukung oleh Santrock (2007: penguasaan kata. Scarborough (2008: 22) 68) yang mengatakan bahwa kesadaran menyarankan bahwa kemampuan fonologi, nama huruf dan pengetahuan membaca semestinya sudah distimulasi bunyi, serta kecepatan penamaan di TK sejak seseorang berada pada tahapan sangat terkait dengan kesuksesan perkembangan usia dini. membaca di kelas pertama dan ke dua. Siswa yang memiliki kesadaran fonologi yang baik akan lebih mudah menjalani proses belajar membaca. Hal ini diperkuat oleh hasil penelitian yang dilakukan oleh

Meskipun kesadaran fonologi sangat penting bagi anak usia dini, namun belum banyak ahli bahasa yang memberikan perhatian pada 
FON ; Jurnal Pendidikan Bahasa dan Sastra Indonesia

Volume 12 Nomor 1 Tahun 2018

perkembangan lesadaran fonologi ini (Peppoloni dan Bonesso, 2017: 33).

Berdasarkan fenomena tersebut, peneliti tertarik untuk melakukan penelitian tentang kesadaran fonologi anak usia 3 tahun. Adapun pertanyaan dari penelitian ini adalah:

"Bagaimanakan perkembangan kesadaran fonologi anak usia 3 tahun pada level kata, suku kata, dan onset-rime?"

\section{METODE PENELITIAN}

Penelitian ini menggunakan metode deskriptif kualitatif dengan pendekatan naturalistik. Tujuan penelitian ini adalah untuk mendeskripsikan kesadaran fonologi anak. Responden pada penelitian ini terdiri atas 3 orang anak usia 3 tahun yang terdiri atas 2 orang perempuan dan 1 orang laki-laki. Tabel di bawah ini berisi tentang data responden.

\begin{tabular}{|l|c|c|c|}
\hline o. & Inisial Nama & \multicolumn{1}{|c|}{ Jenis } & Usia \\
\hline & Qelamin & P tahun 7 \\
\hline & DARP & L & bulan tahun 9 \\
\hline & KKB & P & bulan tahun 2 \\
\hline & & & bulan \\
\hline
\end{tabular}

Table 1.

\section{Nama responden}

Teknik pengumpulan data dilakukan dengan dua langkah yaitu observasi. kerja yang diadaptasi dari PAST Peneliti mengobservasi kegiatan (Phonological Awareness Skills Test) responden yang diminta untuk melakukan kegiatan yang bertujuan untuk melihat kemampuannya dalam mendeteksi dan memanipulasi kata. Adapun instrumen penelitian yang digunakan adalah unjuk yang diterbitkan oleh GRRC (Green River Regional Education Center), Kentucky, Amerika Serikat. Peneliti menggunakan instruksi dan tahapan seperti yang 
FON ; Jurnal Pendidikan Bahasa dan Sastra Indonesia

Volume 12 Nomor 1 Tahun 2018

disarankan oleh GRRC namun diadaptasi menggunakan Bahasa Indonesia sesuai dengan bahasa yang digunakan oleh responden. Di dalam tes ini ada 6 poin yang dinilai yaitu konsep kata, pengenalan bunyi, produksi rima, memadukan suku kata, pemenggalan suku kata, dan penghilangan suku kata.

\section{HASIL DAN PEMBAHASAN}

\section{Pemenggalan Kalimat (Sentence Segmentation)}

Pemenggalan kalimat merupakan tingkatan kesadaran fonologi yang paling rendah. Responden diminta untuk mengidentifikasi bunyi kata di dalam kalimat dengan melakukan permainan kata dan pion. Responden diminta untuk mengucapkan sebuah kalimat dan memindahkan pion pada setiap kata yang ia ucapkan. Hasil PAST menunjukkan bahwa ketiga responden sudah memiliki keterampilan yang baik pada tataran suku kata. Hal ini terlihat dari semua responden dapat melakukan seluruh instruksi dengan benar mulai saat mengidentifikasi kalimat yang terdiri dari 3 kata hingga kalimat yang terdiri dari 5 kata. Ketiga responden mampu mengucapkan kalimat dengan intonasi yang tepat baik itu berupa kalimat pernyataan atau yang berisi pertanyaan.

\section{Pengenalan Bunyi Berima (Rhyme Recognition)}

Pada tingkatan pengenalan bunyi, responden diminta untuk mengenali dua kata yang memiliki bunyi akhiran yang sama misalnya /tas/ dan /jas/. Responden diberikan 6 pasang kata dan menentukan pasangan kata mana yang memiliki rima. Hasil PAST menunjukkan bahwa kedua responden perempuan berhasil mengidentifikasi keenam pasang dengan tepat sementara satu responden laki-laki hanya dapat mengidentifikasi lima dari enam pasang kata dengan benar. DARP keliru saat menentukan kata /langit/ dan /laut/, ia mengatakan bahwa kedua kata tersebut memiliki rima yang sama. Hal ini disebabkan karena responden terkecoh oleh suku kata pertama yang sama. Namun, saat kemudian peneliti mencoba memberikan 3 pasang kata tambahan, responden DARP sudah dapat mengidentifikasi dengan benar.

\section{Produksi Rima}

Selanjutnya, responden diminta untuk menciptakan bunyi yang berima, contohnya pada kata /sapi/ dan /tapi/. Pada tahap ini peneliti melakukan pengujian sebanyak dua kali. Uji yang pertama 
FON ; Jurnal Pendidikan Bahasa dan Sastra Indonesia

Volume 12 Nomor 1 Tahun 2018

menghasilkan bahwa ketiga responden masih memiliki keterampilan yang belum memadai dari produksi rima ini. Dari enam kata /pagi/ /sama/ /tahu/ /biru/ /awan/ dan /hitam/, hanya responden QAC yang dapat membuat rima dari kata/sama/ menjadi /mama/ dan /pagi/ menjadi /gigi/. Responden KKB hanya dapat membuat rima /pagi/ dan /tinggi/. Pada uji kerja yang kedua, peneliti mengajak responden menyanyikan lagu-lagu yang berima seperti "burung hantu" dan "kakak tua" sebelum memulai uji produksi rima. Setelah itu, peneliti meminta responden membuat rima dari kata yang terdapat pada lagu tersebut. Hasil uji yang kedua menunjukkan bahwa responden QAC berhasil membuat 4 kata berima, KKB membuat 5 kata berima, dan DARP berhasil membuat 4 kata berima. Hal ini menunjukkan bahwa keseluruh responden sudah memahami konsep rima dengan baik hanya saja mereka belum memiliki perbendaharaan kata yang memadai untuk membuat rima seperti yang diminta oleh peneliti.

\section{Memadukan Suku Kata}

Hasil PAST menunjukkan bahwa keseluruh responden dapat memadukan suku kata dengan baik. Kemampuan memadukan suku kata dinilai dari kemampuan responden menggabungkan suku kata yang disebutkan oleh peneliti hingga membuat sebuah kata. Hasil observasi menunjukkan bahwa ketiga responden dapat menjalani tes bagian ini tanpa kesulitan yang berarti. Hanya responden $\mathrm{KKB}$ yang terlihat sedikit mengalami kesulitan saat menggabungkan suku kata /ker/ dan /tas/ menjadi /kertas/. Hal ini dikarenakan responden KKB belum dapat mengucapkan bunyi /r/ dengan baik.

\section{Pemenggalan Suku Kata}

Pada bagian pemenggalan suku kata, kegiatan yang hampir sama dilakukan dengan saat pemenggalan kalimat. Responden diminta untuk mengidentifikasi suku kata dengan melakukan permainan bunyi dan pion. Responden menyebutkan kata sambil memindahkan pion setiap kali ia membunyikan suku kata baru. Hasil penelitian menunjukkan bahwa dua responden membuat kekeliruan saat menyebutkan suku kata yang berawalan dengan bunyi /l/ seperti dalam kata /malam/. Responden QAC dan KKB menjadikan bunyi /l/ sebagai akhiran suku kata bukan sebagai awalan suku kata. Mereka memenggal kata malam menjadi /mal/ /am/ bukan /mal/ dan /am/. 
FON ; Jurnal Pendidikan Bahasa dan Sastra Indonesia

Volume 12 Nomor 1 Tahun 2018

Responden juga belum dapat memenggal suku kata yang memiliki konsonan kluster seperti dalam kata /nyebrang/, mereka memenggal kata /nyeb/ dan /brang/.

\section{Penghilangan Suku Kata}

Pada bagian akhir, ketiga responden melakukan uji penghilangan suku kata. Ketiga responden diminta untuk menganalisis suku kata yang tersisa dari sebuah kata yang sebagian suku katanya dihilangkan. Misalnya apabila suku kata /bin/ dari kata /bintang/ dihilangkan, maka responden hanya akan menyebutkan kata /tang/. Hasil penelitian menunjukkan bahwa ketiga responden hanya dapat mengidentifikasi kata yang dihilangkan suku kata pertamanya. Misalnya, apabila suku kata /mo/ dari kata /mobil/ dihilangkan maka responden akan menjawab /bil atau apabila suku kata /ba/ dari kata /baju/ dihilangkan makan responden dapat menjawab dengan tepat /ju/. Hal yang sebaliknya terjadi saat ketiga responden harus mengidentifikasi kata yang suku kata akhirnya dihilangkan. Misalnya, apabila suku kata /mar/ dari kata /kamar/ dihilangkan, responden tidak menjawab dengan suku kata $/ \mathrm{ka} /$ tetapi mengulang kata tersebut.

\section{KESIMPULAN}

Berdasarkan penjabaran di atas, dapat disimpulkan bahwa anak usia 3 tahun sudah memiliki kesadaran fonologi yang baik pada tingkatan pemenggalan kalimat, pengenalan bunyi berima, produksi bunyi berima, dan penggabungan suku kata. Pada bagian produksi bunyi berima, anak usia 3 tahun sudah dapat memproduksi bunyi berima namun kosakata yang mereka miliki belum memadai sehingga terlihat seperti mereka belum memiliki kemampuan pada tahapan tersebut. Pada keterampilan pemenggalan suku kata, anak usia 3 tahun masih dipengaruhi oleh kemampuan pelafalan fonem seperti fonem /r/. Anak usia 3 tahun juga belum dapat memenggal suku kata yang memiliki konsonan kluster. Sementara pada tingkatan penghilangan suku kata, anak tiga tahun baru dapat mengidentifikasi kata yang suku kata pertamanya dihilangkan. Anak tiga tahun belum dapat mengidentifikasi kata yang suku kata terakhirnya dihilangkan.

\section{DAFTAR PUSTAKA}

Copple \& Bredekamp. (2012). Developmentally Appropriate Practice. In Early Childhood 
FON ; Jurnal Pendidikan Bahasa dan Sastra Indonesia

Volume 12 Nomor 1 Tahun 2018

Programs, Serving Children from Birth through Age 8. Washington, DC. National Association for the Education of Young Children.

Dardjowidjoyo, Soenjono, 2000. Echa: Kisah Pemerolehan Bahasa Anak Indonesia. (Jakarta: PT Gramedia Widiasarana Indonesia.

Duranovic, Mirela, Mensur Huseinbasic, dan Sanela Tinjak . 2012.

Development of Phonological

Awareness and Letter Knowledge in

Bosnian Preschool Children .

International Journal of Linguistics, vol. 4 , no. 2

Kuhl, P., Conboy, B., 2008. Phonetic learning as a pathway to language: New data and native language magnet theory expanded (NLM-e). Philosophical Transactions B, 363: 979-1000

Peppoloni, Diana dan Emanuele Bonesso.
2017. Training Phonological Awareness in Children through Pedagogical Technologies: An App for Learning Italian as a Foreign Language. International Journal of Linguistics, Vol. 9, No. 2 hal. 30-56

Santrock, J.W. (2007). Perkembangan Anak. Edisi Kesebelas, Jilid 1. Jakarta: Erlangga.

Scarborough , 2008, Developing Early Literacy Report of the National Early Literacy Pane I-A Scientific Synthesis of Early Literacy Development and Implications for Intervention, (http://lincs. ed. gov/ publications/ pdf/ Nelp Report. Pdf).

Traxler, Matthew. 2011. Introduction to Psycholinguitics. New Yorks; Willey

Trehearne, Miriam. 2003. Comprehensive Literacy Resource for Kindergarten Teachers. Canada: ETA hand2mind 